\title{
The Demography of Globalisation
}

\author{
J L Sadie
}

Department of Economics, University of Stellenbosch

\begin{abstract}
Demographic globalisation, as the counterpart of economic globalisation, is interpreted as the movement towards a state depicted as the "global village" where there are no official impediments to the cross-border movement of people. Such movement is posited as the outcome of inter-country disequilibria which determine the levels of the propensity to migrate. Relevant problems are addressed such as whether the international trade in goods and services can serve as substitute for migration of labour (accompanied or unacompanied by dependents); demographic complementarity between more and less developed countries; the type of labour demanded by countries of immigration; demographically perverse migratory flows; the socio-economic problems ensuing from the formation of numerically strong ethnic minorities in host countries; and what the outlook is for the realisation, in demographic terms, of a global village mode.
\end{abstract}

JEL J 11

\section{THE SUBSTANCE OF GLOBALISATION}

Globalisation is interpreted to depict the process of which the end result is the global village where national boundaries will have no significance for the movement of four of the five factors of production (the fifth being natural resources which are locality bound), and their outputs (goods and services), as well as human beings not subsumed under labour and entrepreneurship. That is, their movement will be unfettered by non-market forces as designed and enforced by national govemments; which does not mean that there could not be legislation (such as labour laws) which does not discriminate between foreigners and natives, but which can nevertheless militate against the economic accommodation of the former. In the year 2001 the process is by no means complete, neither in its economic nor in its demographic (movement of people) connotation. When the governments of affluent communities, for example, raised their agricultural subsidies from $\$ 250$ billion in 1999 to $\$ 330$ billion in 2000 (De Lange, 2000) they did not comply with the spirit of the rules negotiated in the Uruguay round which led to the establishment of the World Trade Organisation. 
And there is hardly a country which does not pursue a restrictive immigration policy.

However, even if the demonstrations in Seattle and Prague could be seen as harbingers that the heady days of (economic) globalisation are over, it would seem to remain the driving force in the world economy (International Business Week $2000 ; 136$ ). And the authors of The Age of Migration believe that the globalisation, the acceleration, the differentiation, the feminisation and politicisation of migration are going to play a major role during the two decades to come (Castles \& Miller, 1998: 8-9). "There can be few areas today which are not profoundly affected by the growing global migratory flows" (Ibid: 103). An analysis by the International Labour Office is reported to have revealed that between 1970 and 1990 the number of countries classified as major destinations of labour migrants rose from 39 to 67 , at the same time as the number of countries identified as major international suppliers of labour increased from 29 to 55 (World of Work, 2000: 7). By 1996 there would have been in excess of 100 million people living outside their country of birth (UN, 1997), rising from 75 million in 1965 to more than 120 million in the year 2000 (World of Work, 2000: 7). And as far as involuntary movement across national boundaries is concemed we have the pronouncement that "mass forced migration is a child of the global era, and promises to be a prominent feature of world affairs" (Kiely \& Marfleet (eds.), 1998: $85)$.

Leaving out of consideration the small minority of persons who move internationally to avoid taxes or escape harsh winters, migrants can be classified into two categories in terms of the push/pull paradigm: (i) economic migrants, permanent or temporary, legal and illegal, accompanied or followed or not by their families and distant relatives; and (ii) refugees, whose movement does not result from a considered choice, and is driven by the necessity to flee their countries by reason of hostilities or oppression which put their lives in jeopardy. Those referred to in the literature as eco-refugees appertain to the first rather than the second category. The pull is the dominant force in respect of the first category, while the push element predominates in the second, though rarely does any one operate in isolation.

Migratory movement can be considered to originate in a situation captured in the disequilibrium:

$\mathrm{W}_{\mathrm{o}} \mathrm{p}_{\mathrm{o}} \mathrm{s}_{\mathrm{o}}<\mathrm{W}_{\mathrm{d}} \mathrm{p}_{\mathrm{d}} \mathrm{s}_{\mathrm{d}}$

in which the $o$ and $d$ subscripts indicate countries of origin and destination respectively, $\mathrm{W}$ stands for wage or income level, $\mathrm{p}$ for the probability of securing a livelihood and $s$ for the social or socio-political environment, with the values 
of $p$ and $s$ varying from 0 to 1 . In the case of refugees the value of $s_{0}$ will be zero, while for economic migrants the perceived value of $s_{d}$ is likely to be lower than $\mathrm{s}_{\mathrm{o}}$, but $\mathrm{W}_{\mathrm{d}}$ or $\mathrm{W}_{\mathrm{d}} \mathrm{p}_{\mathrm{d}}$ will compensate for that.

In the global village state there will, of course, be no difference in the treatment meted out to the two categories. Illegal immigration will no longer exist, while the refugee and the economic migrant will have the same status in the recipient countries. Since the need for clandestine entry into countries of destination will disappear, the trade in human cargo, which often claim lives, should end. "Tighter borders" wrote The Economist "encourage dangerous smuggling of people by criminal gangs who pack hapless travellers into rusty ships, airtight lorries and even beside the wheels of the Paris-London Eurostar" (2001, March 31: 11). Asylum-seekers have suffocated or starved to death in airtight trucks and containers and hundreds who had attempted to land on the Mediterranean coastline, drowned (Kiely \& Marfleet, 1998: 83).

Still, after constraints imposed by government policies have been removed, some others will remain, such as the problem of the economics of distance and inadequate knowledge about prospects in foreign countries. The former has, over the years, lost some of its inhibiting effects as a result of the expansion of the transport systems and the phenomenal drop in the cost of air transport and telephone conversations (World of Work, 2000: 4-7). The latter is being attenuated by recruitment agents, historical links (such as those emanating from onetime colonialism), feedback from preceding emigrants, and other support networks, which means that the process of cumulative causation is likely to continue its reinforcing effect to boost the migratory flows.

But, whether voluntary or involuntary, planned or unplanned, the breadwinners among those moving across national borders expect to become members of the labour force of the recipient countries, while the UN Secretariat, Population Division, has called labour migration "the most inclusive category of population movement" (1992: 1). Also, asylum seeking is a phenomenon which cannot be subjected to the kind of stochastic analysis permitted by deliberate choice migration. At the beginning of the 1990 s there were some 17 million refugees most of whom found asylum in the lesser developed regions (Shah, 1998: 220), (quite likely because of the latter's proximity to the areas of origin). Accordingly, the movement of the factor of production, labour, shall be regarded as a proxy for migration, which factor can then be considered in juxtaposition with the other four: entrepreneurship, capital, technology and natural resources. 


\section{INTERNATIONAL TRADE AS SUBSTITUTE FOR INTER- NATIONAL MIGRATION}

The question can then be posed whether the international movements of the outputs produced by the combination of those factors cannot act as substitute for the migration of labour; that is, whether economic globalisation cannot serve the purposes of demographic globalisation, thus obviating the necessity for the latter. For this to materialise, international trade would have to raise the marginal product of labour, and its remuneration, in the countries of emigration (E) to that of the areas of destination (I), to remove the incentive to migrate. The simplest exercise involves contrasting less developed, low income, regions (LDRs) with youthful fast-growing populations and labour forces, and more developed, high income, regions (MDRs) with slow-growing populations which had already undergone a considerable degree of aging. The former would, ceteris paribus, be the potential source of emigration to the latter because of a desire to improve life chances associated with the higher remuneration of labour in the latter. If, now, countries were to apply the endowment of their factors of production in accordance with their relative scarcity or abundance, the LDRs would produce and export labour-intensive goods and services to the MDRs, while importing from the LDRs capital-intensive products. In the former labour becomes less abundant with a consequential rise in its price, while capital is rendered less scarce. The reverse occurs in the latter. The gap, between the two, in the remuneration of labour is narrowed or closed, and the intensity of the inducement to translocate is reduced or rendered inoperative. The outcome is in line with the Heckscher-Ohlin model. Its realisation will, however, depend upon the real world compliance with certain conditions: each of the factors of production has to be of similar quality in the $\mathrm{E}$ and I countries; factor intensities differ unchangingly from one product to the next; the production function of a tradeable is identical in the two categories of countries; competition prevails which allows the supply of production factors to influence their remuneration; trade reversals do not occur because of changes in domestic demand stemming from population growth, for example; trade does not induce complete specialisation, the LDRs and MDRs producing some of all the products traded. In real life these conditions are seldom, if ever, satisfied.

Arguably the most basic of all inhibiting factors and constituting a barrier that cannot be surmounted by international trade, or which pre-empts the realisation of the required volume and composition of such trade, is the difference in the economic quality of the respective populations as represented by the human capital and enterprising content of the labour forces. Of the two human factors of production comprised in the labour price - labour and entrepreneurship - it is the disparity in the endowment of the latter which is of cardinal importance. The 1 countries' paramountcy in this regard is of the order of $6+$ to 1 (Sadie, 
2000: 188). Emigrants, regardless of whether they might become employees or self-employed in their host country would be attracted to those destinations where supplies of entrepreneurship produce the required or perceived economic opportunities as reflected in the size and growth of the GDP, per capita, or in toto. The amearage of $\mathrm{E}$ countries in respect of this fons et arigo of economic growth and development spells an insufficiency of enterprise to produce the tradeable goods and services required, or to create job opportunities adequate to prevent large scale unemployment and/or underemployment and poverty. An inducement to translocate is forever present. The inducement is likely to be strengthened by economic globalisation since its rules are calculated to eliminate the protection which the infant entrepreneur - a characterisation which applies particularly to those in the LDRs - might otherwise have enjoyed. The emergence of more of those potential generators of employment will be inhibited, and more members of the labour force will need to seek accommodation in MDRs.

If $\mathrm{E}$ countries have well-educated and -trained labour, whose potential comparative advantage is not negated by wage levels not related to volume of supplies, they may attract entrepreneurs from I countries whose employment creation will reduce the inducement and the outward movement. This may not find favour with the Seattle demonstrators who believe that multinationals exploit Third World workers and pollute the environment (Steyn, 2000: 9). Another source of attraction of entrepreneurship and, with it, capital and technology, is the discovery of a rich natural resource, such as oil - or one that has become exploitable with profit because of a rise in world prices - which can change a labour exporting country into a labour importing one. But this may only effect a change in the direction of the flow of migrants rather than ending or reducing it, The Gulf States, for example, became a labour scarce region dependent upon the immigration of Egyptians, Yemenites, Palestinians, Jordanians, Lebanese, Indonesians and others (Shah, 1998: 209; UN, 1998: 383-91, Castles \& Miller: 116118). Saudi-Arabia's dependence on foreign labour was estimated at 27 percent of its labour force in 1970, rising to 53 percent in 1980 and to 79 percent by 1985 (UN 1998: 209). In the massive flow of migrants, during at least part of the 1840-1930 period from the then developed countries to the less developed world (US Report to the President, 1978: 31), we have a demonstration of the attraction of natural resources: wide, open spaces (real and perceived) and/or mineral resources in the United States, New Zealand, Australia, Canada, Australia and South Africa.

In the context of the discussion above the findings of two organisations are relevant. The US Commission for the study of International Migration and Cooperative Economic Development found that in the short run economic development (in E countries) tends to stimulate migration by raising people's expecta- 
tions and enhancing their ability to migrate. It may take many years, perhaps generations, for development to result in low migration (Muus, 1998: 205). The ILO (in Workers without Frontiers: The impact of globalisation on International Migration, 2000) concluded that economic globalisation, for from reducing the international flow of people, is due to intensify migration pressures in the years ahead. "Flows of goods and capital between rich and poor countries will not be large enough to effect the need for employment in poorer countries. Instead, social disruption caused by economic structuring is likely to shake more people lose from their communities and encourage them to look abroad for work" (World of Work, 2000: 4).

Again, the South tends to perceive the benefits and costs arising from economic globalisation to be favouring the more economically powerful, industrialised North (Nel, 2000: 3; Leuvenink, 2000: 5). They have been disillusioned about the performance of the World Trade Organisation. "Developing countries that hoped for substantially enhanced market access have been disappointed by slow or no progress when it comes to vital sectors like textiles and agriculture" (Mead, 2000: 29). If the North will not relent, it may have to offer freer access of labour from the South to its labour market, as a quid pro quo.

It would seem that, with or without significant economic growth and development in the $\mathrm{E}$ countries, prospective migrants would continue to strain at the leash. This applies equally to migration between I countries which offer higher rewards for jobs for which the domestic supply of labour has become inadequate by reason of a rapid development in a segment of the economy, such as the electronic industry. To judge by South Africa's experience, activated demographic globalisation is likely to lead to an increase in temporary migration. Professionals who desire to gain some international experience and, at the same time, earn hard currency incomes which are of average level in the host country but, when translated into Rand, are much higher than salaries in South Africa, accept jobs overseas, for two to three years before returning home.

\section{MIGRATION - PROMOTING DEMOGRAPHIC COMPLEMEN- TARITY}

To discover whether there are demographic bases for an expectation or projection of an increased international movement of people, we can investigate the age structures, fertility and mortality of individual or groups of countries. As before, the comparison is between the two categories of communities or regions, LDRs and MDRs. To confine the exercise to an investigation of purely demographic forces, the 15-64 age interval shall be defined as the manpower age group and, accordingly, the potential manpower (which for statistical purposes, 
without prejudice, shall refer to males) thus leaving out of consideration labour force participation rates (which reduce manpower to labour force levels). Accessions to potential manpower consist of those reaching the age of 15 , while separations are made up of deaths among those 15 to 64 years of age, and retirements occurring by virtue of attaining the age of 65 . The computations are based on the population projections for 2000 and 2005 by the United Nations secretariat in World Population Prospects Volumes I, II, III $(1999,2000)$. The results relating to the MDRs, the LDRs and Sub-Saharan Africa (SSA) are summarised in Tables 1 and 2.

\section{Table 1a Age structures}

\begin{tabular}{|l|c|c|c|c|c|c|}
\hline \multicolumn{3}{|c|}{ MDRs } & \multicolumn{2}{c|}{ LDRs } & \multicolumn{2}{c|}{ SSA } \\
\hline Age & $\mathbf{2 0 0 0}$ & $\mathbf{2 0 0 5}$ & $\mathbf{2 0 0 0}$ & $\mathbf{2 0 0 5}$ & $\mathbf{2 0 0 0}$ & $\mathbf{2 0 0 5}$ \\
\hline $0-14$ & 19,2 & 17,8 & 32,9 & 30,7 & 44,7 & 43,1 \\
\hline $15-64$ & 69,1 & 69,5 & 62,5 & 64,4 & 52,7 & 54,3 \\
\hline $65+$ & 11,7 & 12,7 & 4,6 & 4,9 & 2,6 & 2,6 \\
\hline & 100,0 & 100,0 & 100,0 & 100,0 & 100,0 & 100,0 \\
\hline
\end{tabular}

Table 1b Age structure of age group 15-64, year 2000

\begin{tabular}{|l|c|c|c|}
\hline & MDRs & LDRs & SSA \\
\hline $15-29$ & 31,3 & 43,8 & 52,6 \\
\hline $30-49$ & 44,5 & 41,3 & 35,5 \\
\hline $50-64$ & 24,2 & 14,9 & 11,9 \\
\hline \multicolumn{3}{|c|}{ TFR 2000-2005 } \\
\hline & 100,0 & 2,80 & 100,0 \\
\hline \multicolumn{3}{|c|}{} \\
\hline \multicolumn{3}{|c|}{ Rate of Natural Increase } \\
\hline
\end{tabular}

Sources: Adapted from United Nations, 1999, 2000; volumes 1, 11, 111

It is seen that the MDRs and LDRs have contrasting demographic attributes. At 1,56, the TFR (Total Fertility Rate) of the MDRs - which is below replacement rate - is almost half of that of the LDRs. During the three years 1997 to 1999 that of the European Union has been 1,45 (Sardon, 2000: 730), and the populations of its member countries are either diminishing in number, or are due to decline if they are not supplemented by immigrants. Concomitantly, the MDRs have relatively few children and large numbers of elderly people, while the youthful LDRs have large components of children and small numbers of people 65 years and older. The age structure of the manpower age groups themselves reflect the youthfulness of the latter compared to that of the former, with rela- 
tively large numbers in the age of accession (15-29) and small numbers in the mature age group (50-64). In all these aspects the attributes of the SSA (SubSaharan Africa) are even more pronounced than those of the LDRs as a whole (and accordingly, of the other members of the LDR category).

The above magnitudes can be translated into the components of manpower dynamics by applying Coale and Demeny's (1966) survival ratios as follows: Model North, level 23 for the MDRs, Model South level 20 for the LDRs and Model South level 13 for the SSA. The results, as represented by the changes between 2000 and 2005, are summarised in Table 2.

Table 2 Manpower Dynamics: Percentage change per annum

\begin{tabular}{|c|c|c|c|c|c|c|}
\hline \multirow[t]{2}{*}{ Regions } & \multirow{2}{*}{$\begin{array}{l}\text { Acces- } \\
\text { sions }\end{array}$} & \multicolumn{3}{|c|}{ Separations } & \multirow{2}{*}{$\begin{array}{l}\text { Rate of } \\
\text { Renewal }\end{array}$} & \multirow{2}{*}{$\begin{array}{c}\text { Co-efficient } \\
\text { of Replace- } \\
\text { ment }\end{array}$} \\
\hline & & Deaths & Retirement & Total & & \\
\hline MDRs & 2,02 & $-0,48$ & $-1,30$ & $-1,78$ & 0,24 & 113 \\
\hline LDRs & 3,44 & $-0,48$ & $-0,70$ & $-1,18$ & 2,26 & 291 \\
\hline SSA & 4,80 & $-0,88$ & -0.49 & $-1,37$ & 3,43 & $35 !$ \\
\hline
\end{tabular}

As a result of the relatively low rate of accessions and the high rate of retirement in the MDRs, the rate of renewal (or growth rate) of potential manpower is less than one-tenth of that of the LDRs. Their co-efficient of replacement = $\left[\frac{\text { accessions }}{\text { separations }} \times 100\right]$ at 113 , is only 39 percent of the LDRs'. Whereas the former have to generate only 13 extra jobs to accommodate the growth in manpower after filling the vacancies left by death and retirement, the latter have to create 191. In a stationary job market - i.e. in which only those replacing the separations will be employed - the probability of procuring employment would be 0,88 in the MDRs and 0,34 in the LDRs (all figures are, of course, averages). In SSA countries it will be only 0,28 .

All the above results reflect a high degree of demographic complementarity between groups of nations which should be conducive to an international movement of labour (accompanied or not by dependants) on a large scale. The conditions for its realisation is that there is to be not only complementarity in respect of skills, but also in regard to demand for them in the respective regions or countries. The first condition represents little or no problem: there are large surpluses of low-skilled workers in the LDRs compared to the short supply of them in the MDRs. The skills complementarity are in large measure due to the differential population growth: economic resources spent on quantity reduce the amount available for the enhancement of the quality of human resources. In the MDRs there are large supplies of skilled workers whose marginal social product 
would be in excess of their marginal private product if they were employed in the LDRs, while within the MDRs the two products would probably be equal. The data in Table 3 would appear to bear testimony to the influence exerted, since the $1970 \mathrm{~s}$, by the complementarity, in tandem with the liberalisation of admission policies (Muus, 1998: 1989).

Table 3 Estimated maximum net migration, annual averages

\begin{tabular}{|r|r|r|r|r|r|r|}
\hline $960-64$ & $965-69$ & $970-74$ & $975-79$ & $980-84$ & $985-89$ & $990 / 9$ \\
\hline 706923 & 669144 & 572153 & 171013 & 171324 & 490511 & 180579 \\
\hline \multicolumn{7}{|c|}{ From LDRs to MDRs } \\
\hline 230017 & 391850 & 654658 & 762950 & 890064 & 939616 & 614887 \\
\hline
\end{tabular}

Source: Zlotnik, 1994: 362

Up to the beginning of the 1970 s migration was predominantly between developed countries, but since then the flow from LDRs to MDRs accounted for the major proportion. Asylum-seekers, most of whom originated in the LDRs, would have made some contribution, though they tended to move to equally poor neighbouring countries in the first place. The UN High Commission for Refugees estimated that their numbers rose from two million in total during the late fifties to 27 million by 1995 (Kiely \& Marfleet: 70). Skills differentials would function in harmony with demographic complementarity if the rising per capita income of the MDRs continue to lead to increasing demand for immigrants who are prepared to accept the arduous and menial jobs at low rates of remuneration which indigenous workers if the receiving countries are increasingly reluctant to consider. Rising affluence changes life styles, inducing more leisure to be bought, and leading to a revival of the demand for domestic servants (and entertainers) which favours the immigration of females, eliciting the characterisation of the feminisation of international migration. This has been promoted, it has been argued, by the inferiority ascribed to women in patriarchal societies in countries of departure, which rendered them more docile as workers than men and would be paid lesser wages (Phizaklea, 1983: 5). It has been maintained that the USA, for example, is far more attractive to poorer and less privileged Mexicans than it is for the Mexican middle class (Castles \& Miller, 1998: 90). In Germany's reconstruction after the Second World War the mass production methods required large numbers of low-skilled workers, the so-called Gastarbeiter.

Lately, however, demand for labour in countries of destination has become a force functioning perversely to demographic complementarity. The technological revolution, and I.T. in particular, has been responsible for not only the burgeoning of the "new" or knowledge economy, but has profoundly affected the 
"old" economy as well. Brainpower rather than manual dexterity in manipulative operations is the essential input (Islam, 2000: 20). Germany and the United Kingdom, for example, have schemes in operation to attract high-tech labour. The UK, according to The Economist (2000, Sept: 49) now admits foreign entrepreneurs who have nothing to declare but a good business plan - previously they had to bring in $£ 200000$ with them - and this policy is attributed to the declining fertility and mortality. And the USA immigration Act of 1990 was aimed at increasing the flow of highly skilled foreigners. It has been estimated that in Germany over a period of little more than a generation, some two million jobs for unskilled workers can be dispensed with while 3,4 million new skilled jobs can be generated (Castles \& Miller, 1998: 168). While in South Africa the employment of skilled workers is steadily increasing the numbers of lesser skilled labourers employed are forever diminishing (Statistics SA, 1998).

The resulting movement of people is not only between highly developed economies, but involves also an outflow of high level manpower from the LDRs to the MDRs: the so-called brain drain. The population component in scarce supply is rendered still scarcer. The human capital which costs the LDRs millions to generate is, in effect, being offered as a gift to the MDRs. In Britain, for instance, public hospitals are heavily dependent upon nurses and doctors from Africa and India. The UN has estimated that Africa had lost 60000 doctors, engineers and other professionals between 1985 and 1990, succeeded by an annual outflow of 2000 ever since (Population Today, 2000: 5). Globalisation is, at a minimum, unlikely to reverse the movement.

The flow of migrants (preponderantly illegal) to South Africa from neighboring states appears to be in contradiction to the demographic circumstances. Though the TFR and growth of its population are lower than those in the rest of the SSA, it is still fairly youthful with a large contingent of unskilled workers who are unemployed. This, evidently, does not deter large numbers of unskilled foreign Africans from entering the country. To them the value of $W_{d} p_{d} s_{d}$ is obviously sufficiently in excess of $\mathrm{W}_{\mathrm{o}} \mathrm{p}_{\mathrm{o}} \mathrm{s}_{\mathrm{o}}$ to act as an inducement. To its neighbours West, East and North - South Africa, with its comparatively abundant entrepreneurial endowment, must have the semblance of an affluent country whose GDP per capita is 9,0 times and its aggregate GDP 3,2 times those of its 10 neighbours put together (IMF, 2000; S.A. Institute of Race Relations, June 2001: 6). If they cannot secure paid employment, the alternatives such as street hawking, peddling and other services still offer relatively attractive perceived opportunities. Demographic globalisation is likely to tum this flow into a flood. 


\section{REPLACEMENT IMMIGRATION}

The Population Division of the UN secretariat undertook a study to determine how much replacement in immigration would be required to offset the demographic effects of below-replacement fertility and of aging in a number of developed countries over the period 2000-2050. In three scenarios the following objectives were posited: I constant total population; II constant age group 1564 ; and III constant potential support ratio $\left(\mathrm{N}_{15-64} / \mathrm{N}_{65+}\right)$.

Table 4 Required replacement migration to satisfy three objectives (annual average 2000-2050)

\begin{tabular}{|l|c|c|c|}
\hline \multicolumn{1}{|c|}{ Country } & I & $\mathbf{1 1}$ & $\mathbf{1 1 1}$ \\
\hline France & 29000 & 109000 & 1792000 \\
\hline Germany & 344000 & 487000 & 3630000 \\
\hline Italy & 251000 & 372000 & 2268000 \\
\hline Japan & 343000 & 647000 & 10471000 \\
\hline Republic of Korea & 30000 & 129000 & 102563000 \\
\hline Russian Federation & 498000 & 715000 & 5068000 \\
\hline United Kingdom & 53000 & 125000 & 1194000 \\
\hline United States & 128000 & 359000 & 11851000 \\
\hline Total & 1676000 & 2943000 & 138837000 \\
\hline
\end{tabular}

Source: UN Secretariat, June 2000: 3

It will be seen that the demands upon immigration increase as the objective shifts from I to II and to III: to keep the population size constant 1676000 immigrants per annum would be sufficient to compensate for a projected decline in numbers arising from inadequate natural increase, and should not present an insurmountable problem. The number is almost doubled when the manpower age group has to be maintained in numerical strength, and when the PSR has to be kept constant the required number of immigrants rises by a factor of 47. The latter entails "vastly more immigration than occurred in the past ... [and] seems out of reach ..." (UN 2000 secretariat, 2000: 5). However, the PSR could also be maintained in the absence of migration were the upper limit of the manpower age group to be raised from 65 to 75 . This cannot, of course, guarantee that the size of it labour force would increase proportionally.

Given the propensity to emigrate and assuming demographic globalisation to be implemented, while the value of $s_{0}$ is not very high and of $s_{d}$ not inhibitingly low, LDR and MDR demographic complementary as such should allow the realisation of objectives I and II, and meet some of the migratory demands of objective III. According to our exercise whose results were summarised in tables 1 
and 2 , the manpower age group of the LDRs would be expanding at a rate of 34 892000 p.a. during 2000-2005, adding millions to the unemployed/underemployed (males), compared to 949000 p.a. for the MDRs. The total number of migrants involved in the movement of members of the manpower group would, of course, be boosted by a factor of two or more arising from the accompaniment of families and other relatives.

However, in the last resort, demographic complementarity is not a sufficient condition for the attainment of the above, or similar, objectives. The propensity to migrate has to be appropriate, and an assumption of unlimited intemational mobility of people would be flawed. Except in the case of asylum-seekers (a zero value for $s_{0}$ ) the lower value of $s_{d}$ compared to $s_{0}$, and the economics of distance would hold the propensity in check. Migratory flows under conditions defined by the Global Village State will facilitate the estimation of its level(s). In 1998 the Southern Africa Migration Project attempted to collect some informa tion about the phenomenon among a sample of skilled workers in South Africa. Four questions were asked ranging from the most general to the most pertinent ones relating to the desire or propensity to emigrate:

1. The degree of thought given to leaving the country: more than two-thirds responded positively and 38 per cent declared that they had given it a great deal of thought;

2. A strong desire to leave for a period of two years or more: 28 per cent;

3. How likely is the wish to be translated into reality? 3 per cent said they would leave within six months, 5 per cent within the ensuing two years while 13 per cent asserted that they were "very likely" to leave within 5 years;

4. How many had already started to prepare for emigration? 6 per cent had applied for work permits overseas, 6 per cent had applied for permanent residence in a foreign country while 3 per cent had put in applications for foreign citizenship (Mattes \& Richmond, 2000: 10-20).

Such a variety of probing questions and of responses leaves us with a great deal of uncertainty about the intensity of the intentions to emigrate. Since it is a function of knowledge of prospects abroad, there is also likely to be a difference in this regard between skilled and unskilled workers. Uncertainty is heightened when regard is had to the disparity in numbers of South Africans registered as emigrants by Statistics SA and the numbers who have settled overseas as reported by the five recipient countries: United Kingdom, USA, Canada, New 
Zealand and Australia. The respective figures for the period 1989-1997 are 82 811 and 233609 (Brown et al., 2000: 41-47).

Looked at from the point of view of the LDRs, in light of the above magnitudes, and taking into account the probable propensity to emigrate, the moot question is whether demographic globalisation is likely to make a significant difference to the pressure of population or overpopulation - at given levels of economic development - of these regions. The disparity between the two categories of regions is so vast that the answer must be in the negative. The UN has estimated that the estimated 9,9 million (net) migrants to the more developed regions during 1995-2000 would have accounted for 61 percent of population growth in that part of the world, but would have reduced it in the rest of the world by no more than 2,6 per cent $(2000$, Vol 111: 128). The only effective remedy appears to be economic development in the LDRs coupled with a curbing of fertility. Poverty is likely to endure.

\section{SOCIO-ECONOMIC ACCOMMODATION IN RECIPIENT COUNTRIES}

The kind of socio-economic accommodation of immigrants in the recipient countries seems to be a function of their occupational status. The buzz words in this connection are the "wired" and the "unwired", the former referring to the intelligent and well-educated migrants and the latter to the lesser skilled who do not participate employment-wise in the technological revolution. Globalisation is particularly beneficial to the former, the majority of whom are likely to hail from countries of a Western orientation and to be going to countries with a similar culture. They are assimilated with facility, most of them disappearing into the middle class multitudes of the host communities.

The movement of the lesser skilled would involve, for the most part, a trek from the South to the towns and cities of the North. They would have been nurtured in cultures different from those of the recipient countries, would be operating in a segmented labour market, would have a different skin pigmentation; therefore conspicious and, accordingly, easily recognisable. (While it is not true of African immigrants in South Africa, they are obviously still readily identified by Black South Africans as foreigners and as a potential, or actual, threat to their livelihood). They would tend to cluster together in specific areas to contend with social disadvantage, to enjoy the benefits of similarity of culture or language, of mutual support, and of the opportunities offered by the economics of ethnic conglomeration to mobilise, among their compatriots, custom for informal business enterprises. Such clustering can also provide some security against attacks from the natives of the host country who might see in the growing num- 
bers in these ethnic enclaves a threat to their national identity and cultural dominance, which culminates in the phenomenon of xenophobia or racism. When globalisation leads to increases in the size of these ethnic groups to meaningful proportions, while the fertility of the host communities continues to fall, or do not rise above 2,1 , and projections to show that native populations may become minorities in due time, the perceived threat would undoubtedly loom large. Xenophobia would be intensified and increasingly become an issue in politics. The growth of Third World populations in Europe has prompted the emergence of populist right wing movements (Cohen \& Joly, 1989). The establishment of such cultural and residential enclaves militates against an assimilation approach towards immigrants and favours multiculturalism. Adversative relationships are exacerbated.

\section{THE LIMITS TO GLOBALISATION}

Arising from the above considerations the moot question is whether immigration is likely to be given the free rein as assumed under globalisation. The response has to be: hardly likely. It has already been noted that the demand for labour in I countries is, for the most part not compatible (or at least no longer) with the supplies emanating from the $E$ countries. What the former desire most can be inferred from the type of person they recruit and/or accord preference to, and they are the highly skilled workers who are needed in the technological age. To the extent that the LDRs do indeed supply the MDRs some of this type of manpower, international migration is operating perversely: the former are subsidising the latter and at the same time - since this manpower is a prerequisite for the creation of employment to those lower down in the skill hierarchy - they are leaving behind a greater need, for the lesser skilled, of opportunities to migrate to countries where they are not needed or desired. Some of the latter would no doubt want to repatriate unemployed immigrants - since they are hard put to find jobs for native born low-skilled workers - if they had not been apprehensive of standing accused of being devoid of compassion. These unemployed remain a burden on the public purse by way of their entitlement to every kind of public service (transport, housing, education, health and welfare services, etc.). When Southeast Asia experienced their financial crisis, the governments of the ailing economies planned to repatriate millions of foreign workers, among them 2,5 million from Malaysia and Thailand (Cumming-Bruce, 1998: 17).

"A wave of anti-immigrant sentiment is washing across the continent" wrote The Economist (May 2000: 21-25). "These new arrivals are popularly perceived as welfare scavengers, jobs-snatchers and threats to stability". Europeans blame their 16 million legal immigrants and large numbers of illegals for stealing jobs, raising crime rates and straining welfare budgets. The incidence of crime 
among immigrants is three times higher than among native Europeans (Echikson, 2000: 20-24). In France unemployment among immigrants is $2 \frac{1 / 2}{2}$ times higher than among the rest of the population (Castles \& Miller, 1998: 162; Schott, 2000: 10). Anti-immigrant political movements have been springing up across Europe, and attracted a good deal of support from electorates. And when the aims and political orientation of immigrant communities in a democratic country are basically anti-democratic, the host faces a serious dilemma. In South Africa xenophobia seemed to have reared its head when Xhosa-speakers chased refugees, who hailed from Burundi, Angola, Nigeria and Namibia - accused of competing for the limited number of jobs - from their homes in Milnerton (near Cape Town) (Cruywagen, 2001: 6).

It was probably with the above types of situation in mind that the 1994 World Conference on Population recommended that "policies and development initiatives should be encouraged that would make the option of remaining in one's country a viable one for all people" (UN secretariat, 1997: 2). The European Union's actions would qualify as such initiatives when they subsidised economic development in the poorer member countries before allowing freer movement of labour from them (Smith, 2000: 34), and when it provided funding for the infrastructure of North African states as a quid pro quo to the latter for controlling emigration to Europe (Balibar, 1991: 188). Consonantly, it has been maintained that "planned and controlled entries are conducive to acceptable social conditions for migrants as well as to relative social peace between migrants and local people" (Castles \& Miller: 285).

The limits to demographic globalisation have been best spelled out as follows: "The rules of modern migration are clear. Desirable migrants with skills, education and capital are let in, undesirables, illiterates, poor people from different cultures, religions and "races" are filtered out: globalisation is a process of social exclusion" (King, 1995: 26). In other words, even while some persons might, in the new age of migration, be accorded greater freedom of movement internationally, it is not going to assume the dimensions of a demographic globalisation on a par with economic globalisation. Demographically speaking, the global village mode is an unlikely outcome.

\section{ENDNOTES}

1 It could be that the use of the word here refers to no more than the involvement of ever increasing numbers of countries in migration flows, which can be, but need not be, a result of globalisation as interpreted by the present author. 


\section{REFERENCES}

1 BALIBAR, F., (1991) "Es Gibt Keinen Staat in Europa: Racism and Politics in Europe Today", New Left Review as quoted in Kiely \& Marfleet, Globalisation and the Third World.

2 BOTHMA, P. (2001) "Xenofobie Wek Kommer", Die Burger, February 14: 13 .

3 BROWN, M. et al. (2000) "The Brain Drain - An Outline of Skilled Emigration from South Africa", Africa Insight, October: 44-47.

4 CASTLES, S. \& MILLER, M.J. (1998) The Age of Migration, Guilford Press, New York.

5 COALE, A.J. \& DEMENY, P. (1966) Regional Model Life Tables and Stable Populations, Princeton University Press.

6 COHEN, R \& JOLY, D. (1989) "The 'New' Refugees of Europe" in Reluctant Hosts: Europe and its Refugees, Aldershot, Avebury.

7 CRUYWAGEN, V. (2001) "Wedywering om Werk Lei tot Vreemdelinghaat", Die Burger, January 10:6.

8 CUMMING-BRUCE, N., (1998) "When Tigers Stumble", World Press Review 45(4) April: 17.

9 DE LANGE, J. "Erwin Maan oor Ongebalanseerde Handelsreëlings", SakeBurger, January 29: S 13.

10 DE LANGE, J. (2001) "Subsidies vir Landbou in Ryk Lande Warm Patat op Agenda", Sake-Burger, January 29: 2.

11 DE LANGE, J. (2001) "Vernou die Gaping tussen Ryk en Arm", Die Burger, February 2:9.

12 DE LANGE, J. (2001) Globalisering Maak Armes Armer Mbeki", Die Burger, January 29: 2.

13 DYER, G. (2001) "Globalisering Eerder 'n Uitkoms vir Armer Lande", Die Burger, February 12: 6.

14 ECHIKSON, W. et al. (2000) "Unsung Heroes", International Business Week, February 28: 20-24.

15 ECONOMIC COMMISSION FOR EUROPE (1998) "Intemational Migration in the ECE Region", in United Nations 1998, Population Distribution and Migration: $379-82$.

16 FORD, P. (2000) "People Smuggling, Global Scourge", The Christian Science Monitor 92 (137). June: 1, 10.

17 FUTURIST (2000) "Senior Workers on the Rise", Sept-Oct: 19.

18 GIDDENS, A. (1999) "Globalisation", BBC Reith Lectures, International Business Week 2000, "Globalisation - Lessons Leamed", November 6: 136.

19 HECKSCHER, E. (1919) "The Effects of Foreign Trade on the Distribution of Income", Economisk Tidskrift 1919 reprinted in Ellis, H. \& Metzler, L. (eds.) 1950, Readings in the Theory of International Trade (Philadelphia). 
20 INTERNATIONAL MONETARY FUND (2000) International Financial Statistics Yearbook.

21 ISLAM, F (2000) "Let Them in - It'll Pay", World Press Review 47(9), September: $19-20$.

22 KEYSER, G. (2001) "Asielsoekers Toenemend Truksvy in Wes-Europa", Die Burger, March 3: 12.

23 KIELY, R. \& MARFLEET, P. (eds.) (1998) Globalisation and the Third World, Routledge, London.

24 KING, R. (1995) "Migrations, Globalisation and Place" in Massey, D. \& Jess, P. (eds) A Place in the World, Oxford Univ Press.

25 LEUVENNINK, J. (2000) "Wêreld Moet Besin oor Gelyke Handelsdeelname", Sake Burger, August 29: 5,4.

26 MATTES, R \& RICHMOND, W. (2000) "The Brain Drain - What Do Skilled South Africans Think?", Africa Insight, October: 10-20.

27 MATTES, R et al. (2000) "The Brain Gain and Legal Immigration to PostApartheid South Africa", Africa Insight, October: 21-20.

28 MEAD, W. (2000) "The case for Capitalism", World Link, Sept/Oct: 28-30.

29 MESO, W. (2000) "The Migration of Skills and Labour", Africa Insight, October: 2.

30 MUUS, P. (1998) "South-to-North Migration" in United Nations 1998 (Population Distribution and Migration: 195-207.

31 NEL, P, TAYLOR I, VAN DER WESTHUIZEN (2000) Mbeki's Global Initiative: The Limits of a Reformist Agenda, Institute for Futures Research, Political Issues 10(7) July.

32 OHLIN, B. (1933) International and Interregional Trade (Cambridge).

33 PHIZAKLEA, A. (ed.) (1983) One Way Ticket? Migration and Female Labour (Rontledge \& Kegan Paul London).

34 POPULATION TODAY (1998) "World Refugees Displacement Rising, Few Finding Refuge" 26(3) March: 5.

35 RADEMEYER, C. (2000) "Stroom Uit SA al Dikker", Rapport: December 3: 16 .

36 ROGERSON C.M. \& J.M. (2000) "Dealing in Scarce Skills Employer Responses to the Brain Drain in South Africa", Africa Insight, October: $31-40$.

37 RUSSELL, S.S. (1998) "Migration between Developing Countries in SubSaharan Africa and Latin America" in Untied Nations 1998, Population Distribution and Migration, 228-46.

38 SADIE, J.L. (1994) "South African Population Prospects", Demography $4(1): 1-11$.

39 SADIE, J.L. (1994) "Economic Implications of Demographic Ageing in South Africa", Demography 4(1), October: 40-57.

40 SADIE, J.L. (2000) "The Economic Demography of South Africa", D.Comm dissertation, University of Stellenbosch. 
41 SAKE-BURGER (2001) "Globalisering Moet Inklusief Wees", p. S.1.

42 SARDON, J-P (2000) "Evolutions Recentes de la Demographie des Pays Développés", Population, Jul-Oct No 4-5.

43 SCHLEMMER, L. (2000) "Future in Jeopardy", Frontiers of Freedom, SA Institute of Race Relations, No. 26.

44 SCHOTT, H. (2000) "Word Immigrasie vir Europa Vloek of Seën?", Die Burger, November 16: 10.

45 SHAH, N.M. (1998) "Migration between Asian Countries", in United Nations 1998. Population Distribution and Migration: 208-227.

46 SHUSCHENG, L. \& RIBAO, S.S.J. (2000) "News of the New Economy", World Press Review, November: 39.

47 SMITH, G. (2000) "It's Time for Us to Let in More Mexicans", International Business Week, June 5: 34-35.

48 SOUTH AFRICAN INSTITUTE OF RACE RELATIONS (2001, 2000, 1999, 1998) South Africa Survey, Natal Witness Commercial Printers.

49 STATISTICS SOUTH AFRICA $(1995,1996,1997,1998,1999)$ October Household Survey, Statistical Release P0317.

50 STEYN, P. (2000) "Vandag se Aktiviste is die Keerwal teen 'Bose' Globalisering", Die Burger, September 14: 9.

51 STEYN, P. (2000) "VSA al Afhankliker van Immigrante", Sake Burger, September 5: 1 .

52 THE ECONOMIST (2000) "Immigration after the Flood", 356 (8182) September 9-15: 49.

53 THE ECONOMIST (2000) "The Case for Globalisation", 356 (8189), September 23: 17-18.

54 THE ECONOMIST (2000) "The Last Frontier", 355 (8176) June 24: 47 48.

55 THE ECONOMIST (2001) "Let the Huddled Masses in", March 31: 11.

56 THE NATIONAL GEOGRAPHIC (1999) Desk Reference.

57 UNITED NATIONS (1997) International Migration Policies, New York.

58 UNITED NATIONS (1999) World Population Prospects, Vol. I, The 1998 Revision, New York.

59 UNITED NATIONS (1999) World Population Prospects, Vol. 11, The 1998 Revision, New York.

60 UNITED NATIONS, (2000) World Population Propects, Vol. III, New York.

61 UNITED NATIONS (2000) Long-Range World Population Projections, New York.

62 UNITED NATIONS SECRETARIAT (1997) "International Migration Policies", Population Newsletter, June: 1-6.

63 UNITED NATIONS SECRETARIAT (2000) "Replacement Immigration: is it a Solution to Declining and Ageing Populations?", Population Newsletter, 69 (Population Division): 1-5. 
64 UNITED NATIONS SECRETARIAT, (1998) Population Distribution and Migration, Expert Group Meeting in Santa Cruz, Bolivia 1993, New York.

65 UNITED NATIONS SECRETARIAT, (2000) "World Population Monitoring 2000: Population, Gender and Development", Population Newsletter, 69: 6-9.

66 UNITED NATIONS SECRETARIAT, (2000) "World Urbanization Prospects: The 1999 Revision", Population Newsletter, 69: 10-12.

67 UNITED STATES OF AMERICA (1978) The Global 2000, Report to the President, 11.

68 WORLD OF WORK (2000) "Africa's Brain Drain" 28(3) April: 5.

69 WORLDLINK (2000) "Mental Block", Nov-December: 16-21.

70 ZLOTNIK, H. (1994) "International Migration: Causes and Effects" in Mazur L.A. (ed.) Beyond the Numbers, A Reader on Population, Consumption and the Environment, Island Press, Washington, Cited in U.N. 1998: 198. 